装置取扱マニュアル，機器管理台帳をすべてオンライン化し一元管 理を行い，技師業務の省力化をはかったので報告する．

【方法】(1) 検査台帳入力に関しては, 患者情報入力をオーダーリング から取得し, 必要項目を選択入力し, 極力キーボード入力をなくす こと. 統計処理に関しても検査別, 装置別等の集計が容易にできる こと. (2) 装置，および検査マニュアルはWeb機能を用いて作成し， 検査台帳からすぐに閲覧できること。(3)機器管理台帳はすべての装 置, 関連機器を登録し, 故障, 不具合, 点検, 改善要求の項目に分 け, 小さなこともすべて人力することにより, 必要に応じて修理報 告書が作成できることとする.

【結論】(1) 検査台帳をオーダーリングとオンライン化することにより 患者情報入力のバーコードリーダーで行うことで入力ミスがなくな り, また，データベースソフトを利用することにより, 統計, 集計 が簡素化された（2）検査マニュアルを作成することで，担当者以外 の技師が緊急時検查につく場合に有効に利用されている。（3)機器管 理を一元管理することにより, 機器管理業務を簡素化できたことは もちろん，装置に関する要望が担当者以外の技師からも聞けるよう になり，メーカーへの要望や工夫に生かすことが可能となった。 ま た, 装置のトラブル時にも過去の事例を簡単に参照でき, 対応が迅 速に行えるなど，非常に有用なシステムとなった。

147 リュースパソコンとサーバを用いた集中管理型学生用パソコ ンネットワークシステムの構築

名古屋大学・医学部保健学科 津坂昌利

名古屋大学大学院・医学系研究科 村井 誠

【目的】リースアップされた中古パソコンを活用し，サーバから集中 管理できる教育用のパソコンネットワークシステムを構築する。

【方法】クライアントパソコンのOSには，アカデミックライセンスに よって購入したWindowsXPを使用した。サーバ用OSには Windows2003サーバを用い, ファイアウォールでセキュリティを確保 した学生専用のネットワークを構築した. ウイルス対策も考慮した。

【結論】24時間使用できる専用の部屋を用意し, 図書館にも同様のシ ステムを導入した。学生はいつでもどこでもパソコンとインター ネットを活用することができる。これからの大学教育には, 学生の セルフラーニング(自己学習)を進めるために, 豊富な情報機器の設 置が求められており，安価な費用で効果的なシステムを構築するこ とができた. システムの構築法とその構成, 設置後の効果について 検討したので報告する.

\section{0 台同時アクセス可能な3D画像作成システムの負荷試験} 名古屋大学・医学部保健学科 津坂昌利 名古屋大学大学院・医学系研究科 村井 誠

【目的】ネットワーク対応型3D画像作成システムを用いて，複数クラ イアントからの同時アクセスを行った場合のパフォーマンスを測定 する.

【方法】ネットワーク対応型3D画像作成システムとして, テラリコン 社のAquariusNETを用いた。このサーバに専用3D作成ボードを 4 枚 搭載し，ギガビットネットワークを用いて 20 台のパソコンから同時 アクセスして3D画像を動画表示させ，最も負荷のかかる状態でネッ トワークトラフィックを測定した。 また, 圧縮画像モードを選択し た場合のCPU負荷とパフォーマンスを同様に評価した。

【結論】電子カルテシステムの普及によって, 3D画像の院内配信要求 も高まっている。また, 病診連携や遠隔医療への応用も可能であ る。この場合，ネットワークに与える負荷を評価しておく必要があ る. 今回の測定で, 非圧縮モードではクライアントパソコン 1 台あ たり約20Mbps程度の帯域を使用し，100Mbpsのネットワークでは， クライアント 4〜5 台で带域を使い果たす。圧縮モードでは帯域は 2〜3Mbpsとなり，十分実用的な值になった．臨床的には，同時に20
台ものクライアントから3D動画を観察するような負荷は考えられな いが，最も負荷のかかる最大情報量で結果を評価したが，十分に臨 床で使用できる能力があった。

149 放射線安全教育における e-Lerningの導入

獨協医科大学・放射線管理室 高橋克彦、川島明美

【はじめに】放射線診療業務に従事する職員に対する安全教育は，そ の内容が業務每に異なり，放射線の知識が受講者により差の大きい ことが特徵である．そのため，業務別に細分化した教材と，少人数 の講習会が頻繁に必要になってくる。こうした現状の中で, 我々は インターネットとパーソナルコンピュータを利用したe-Lerningによ る教育訓練支援教材を開発したので報告する.

【方法】今回我々は, インターネットとパーソナルコンピュータを用 いたe-Lerningを検討し，Webブラウザを利用した教育訓練支援教材 を開発した．Webブラウザ上で表示する設問，解答，解説デー夕は HTMLを用いて記述した。 その正䛊判定や解説の表示は，動作速度 が速く，代表的なWebブラウザ上で広く普及しているJAVA Scriptで 制御した。

【結果】放射線安全講習会では，定められた時間に同時に数十人が パーソナルコンピュータ上で問題に取りかかるため, サーバーへの 同時アクセスによる応答速度の低下が懸念された。しかしながら， 20 人 30人の同時利用では応答速度はほとんど低下しないことが 解った．さらに出題者側では, サーバーに問題をアップロードする だけで講習の準備が可能となるほか, 出題内容の変更も容易に行え るという利点があった。受講者側は，業務内容に合った講習内容を 自分のペースで受講できるようになった。

【考察】現在の講習では，受講者を講習室で一定時間拘束して自習を 行う方法をとっている。 しかし講習方法を工夫すれば，インター ネットにつながれたコンピュータから，時間と場所の制約なしに受 講可能となる。これを実現するために，受講者が不正なしに正しく 学習したかどうかを判定できる仕組みの導入が必要である。一例と して, 問題開始時間と終了時間を, 出題者側のみが知ることができ る機能を検討中である。

\section{0 撮影距離が被ばく線量に与える影響}

藤田保健衛生大学・衛生学部診療放射線技術学科 谷本恵子 藤井志保, 州浜千里, 浅田恭生, 鈴木昇一

金沢大学・医学部保健学科 越田吉郎

【目的】平成15年の第56回診療放射線技師試験において被ばく低減に 関する問題の中に, “X線撮影で患者の被ばく線量を軽減する効果の ないのはどれか.”の設問の選択肢に，“X線管とフィルムとの距離を 短くする.”というものがあった。今回，その設問に関する解答を得 るため実証試験を行った。

【方法】受光部側の照射野, 出力線量を一定として線源画像受光部間 距離(SID)を変化させた場合の入射線量を比較した。管電圧は $50 \mathrm{kV}$ から $130 \mathrm{kV}$ ，ファントム厚さを $5 \mathrm{~cm}$ から $20 \mathrm{~cm}$ ，照射野を $5 \times 5 \mathrm{~cm}$ から $20 \times 20 \mathrm{~cm}$ に変化させ，撮影距離 $50 \mathrm{~cm}$ から $200 \mathrm{~cm}$ での入射線量を求め た. 出力線量は同一となるような条件を設定した.

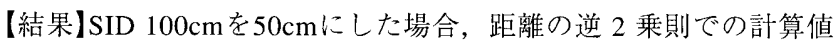
は，厚さ $10 \mathrm{~cm}$ において入射線量はほぼ 5 倍となるが，測定では，照 射野 $10 \times 10 \mathrm{~cm}$ で 5 倍程度, $20 \times 20 \mathrm{~cm}$ で 7 倍を超えていた。管電圧の 変化では管電圧が低いほど差が大きくなった．SIDの変化による差 はほとんど生じなかった、SIDが $1 / 2$ となった場合, 受光部の線量 は単純計算 4 倍となるが，入射線量はそれ以上に増加した，照射野 が大きいほどその差は大きく，距離を短くした場合には線量増加し た．SIDを長くすれば被ばく低減となることが明らかとなった。 